\title{
Inventory Information System on Goods Stock in PT Berkatmas Mulia Guna
}

\section{Sistem Informasi Inventory Stok Barang Pada PT Berkatmas Mulia Guna}

\author{
Mochamad Yuse Waramitha \\ \{ywaramitha@gmail.com\}
}

Program Studi Informatika, Fakultas Sains dan Teknologi, Universitas Muhammadiyah Sidoarjo

\begin{abstract}
Stock Inventory Information System is a system used to enter inventory data for incoming and outgoing goods into the database, controlling inventory, and providing inventory information. So that there will be no errors in data input, data output, and report results based on the desired data. PT Berkatmas Mulia Guna is a company engaged in HVAC (Heating, Ventilation, and Air Conditioning) contractors. Includes new installation of HVAC machines and systems, maintenance and repair of HVAC systems. PT Berkatmas Mulia Guna also includes manufacturing HVAC machines such as AHU, FCU, Exhaust Fan, Supply Fan and Heating. A lot of data changes and a long process of stock data collection from suppliers and customers in the process of processing inventory data, will result in inaccurate data obtained. In inventory data collection, recording of incoming and outgoing goods still uses a manual process with excel which can result in duplicate data or duplicate data for processing inventory data. Based on this problem, the authors conducted a study entitled "Inventory Information System Stock Goods at PT. Berkatmas Mulia Guna "which aims to make it easier to handle the stock inventory process, data entry and exit, delivery of goods, so that the inventory process of goods is faster and more precise. This application system development method uses the waterfall method which consists of six stages. The stages are System Analysis and Design, software requirements analysis, system design, coding, system testing and maintenance. In making this application using a desktop-based website programming language for the Windows operating system, and using the MySql database.
\end{abstract}

Keywords - Contractor; Data Processing; Inventory System; System Aplication

\begin{abstract}
Abstrak. Sistem Informasi Inventory Stok Barang adalah sebuah sistem yang digunakan untuk memasukkan data persediaan barang masuk maupun barang keluar ke dalam database, mengontrol stok barang, dan memberikan informasi persediaan barang. Sehinggga tidak akan terjadi kesalahan dalam input data, output data, dan hasil laporan berdasarkan data yang diinginkan. PT Berkatmas Mulia Guna merupakan perusahaan yang bergerak di bidang kontraktor HVAC ( Heating, Ventilation, dan Air Conditioning ). Meliputi instalasi pemasangan baru mesin dan system HVAC, perawatan dan perbaikan system HVAC. PT Berkatmas Mulia Guna juga meliputi pembuatan Mesin HVAC seperti AHU, FCU, Exhaust Fan, Supply Fan dan Heating. Perubahan data yang banyak dan proses pendataan stok barang yang panjang dari surat jalan supplier maupun pelanggan dalam proses pengolahan data persedian barang, akan mengakibatkan ketidak akurat data yang di dapat. Dalam pendataan stok barang, pencatatan barang masuk dan barang keluar masih menggunakan proses manual dengan excel yang bisa menimbulkan data duplikat atau data ganda untuk proses pengolahan data persediaan barang. Berdasarkan permasalahan ini, penulis melakukan sebuah penelitian yang berjudul "Sistem Informasi Inventory Stok Barang Pada PT. Berkatmas Mulia Guna" yang bertujuan dapat memudahkan dalam menangani proses persediaan stok barang, pendataan barang masuk dan keluar, pengiriman barang, sehingga proses inventory barang lebih cepat dan tepat. Metode pengembangan sistem aplikasi ini menggunakan metode waterfall yang terdiri dari enam tahapan. Adapun tahapan tersebut yaitu Analisis dan Perancangan Sistem, analisis kebutuhan perangkat lunak, perancangan sistem, pengkodean, pengujian dan pemeliharaan sistem. Dalam pembuatan aplikasi ini menggunakan bahasa pemograman website yang berbasis desktop untuk sistem operasi windows, dan menggunakan database MySql.
\end{abstract}

Kata Kunci - Kontraktor; Pengolahan Data; Sistem Inventory; Aplikasi Sistem

\section{Pendahuluan}

PT Berkatmas Mulia Guna merupakan perusahaan yang bergerak di bidang kontraktor HVAC (Heating, Ventilation, dan Air Conditioning). Meliputi instalasi pemasangan baru mesin dan system HVAC, perawatan dan perbaikan sistem HVAC. PT Berkatmas Mulia Guna juga meliputi pembuatan Mesin HVAC sebagai contoh AHU, FCU, Exhaust Fan, Supply Fan dan Heating.

Setiap barang yang masuk atau yang datang dari supplier, akan diperiksa oleh bagian karyawan gudang, kemudian supplier akan memberikan surat jalan kepada pihak gudang untuk memberi tahu barang yang datang. Selanjutnya akan dilakukan pengecekan oleh gudang sesuai surat jalan yang di terima dari supplier. Setelah dilakukan pengecekan oleh gudang, selanjutnya akan memberi informasi barang yang masuk kepada bagian kantor. Sedangkan untuk proses 
barang keluar, bagian gudang harus melapor ke admin kantor dan menyampaikan barang yang akan di keluarkan, kemudian admin kantor mencetak dan memberikan surat jalan yang berisi rincian barang yang dipesan oleh bagian admin gudang.

Sampai saat ini proses pengolahan data, persedian barang dan stok barang masih dikerjakan secara manual oleh bagian admin gudang, data penerimaan barang serta pengeluaran barang hanya dicatat dibuku yang berisi rincian barang sesuai surat jalan dari pelanggan atau supplier. Untuk perhitungan stok barang, hanya dicatat di lembaran kertas oleh admin gudang, data stok yang sudah ditulis manual oleh admin gudang, akan disalin kembali oleh admin kantor ke komputer untuk melakukan update terbaru stok barang. Dari permasalahan tersebut sering terjadi kesalahan dalam menghitung stok barang, kesulitan mencari data dalam bulan tertentu dikarenakan terjadi penumpukan berkas yang banyak, dan pada saat update stok barang secara manual akan membutuhkan waktu yang lama.

Aplikasi dari Sistem Informasi Inventory Stok Barang Pada PT Berkatmas Mulia Guna diharapkan dapat mempermudah dalam menangani persediaan stok barang, pengiriman barang, pendataan barang masuk dan barang keluar, sehingga sistem yang dibangun akan mempermudah pekerjaan pada PT Berkatmas Mulia Guna untuk mengontrol dan mengelola data dalam persediaan stok barang.

Untuk melakukan langkah - langkah dan pembangunan program sesuai metode yang terstruktur, dibutuhkan konsep untuk membangun sebuah sistem terdiri dari :

1. Flowchart adalah gambaran dari alur dan urutan dari suatu program. Flowchart bisa mempermudah pembangunan atau pengambangan suatu program.

Tabel 1. Simbol-simbol Flowchart ${ }^{[5]}$

\begin{tabular}{|c|c|c|c|}
\hline No & Gambar & Simbol & Keterangan \\
\hline 1. & & Awal atau Akhir & $\begin{array}{l}\text { Simbol tersebut diguakan sebagai awal atau akhir } \\
\text { sebuar alur program. }\end{array}$ \\
\hline 2. & & Persiapan Proses & $\begin{array}{l}\text { Gambar tersebut digunakan sebagai pilihan nilai } \\
\text { awal dari suatu variabel. }\end{array}$ \\
\hline 3. & & Pengolahan proses & $\begin{array}{l}\text { Gambar tersebut digunakan untuk memperoses } \\
\text { suatu pengolahan arimatika dan pemindahan data } \\
\text { dari suatu variabel sebelumva }\end{array}$ \\
\hline 4 & & Keputusan & $\begin{array}{l}\text { Gambar tersebut digunakan untuk memperlhatkan } \\
\text { suatu operasi dari perbandingan ligika yang telah } \\
\text { di lakukan. }\end{array}$ \\
\hline 5. & & $\begin{array}{l}\text { Masukan/Keluaran } \\
\text { Proses }\end{array}$ & $\begin{array}{l}\text { Gambar tersebut digunakan untuk menyakan suatu } \\
\text { proses yang dilakuan input dan output. }\end{array}$ \\
\hline 6 & & Garis & $\begin{array}{l}\text { Gambar tersebut digunakan untuk menyatakan } \\
\text { alur/urutan pelaksanaan suatu proses. }\end{array}$ \\
\hline
\end{tabular}

2. Data Flow Diagram (DFD) adalah penggambaran secara logika dari sebuah sistem.Gambaran ini terdiri dari interface dan hasil tampilan yang di perlihatkan tidak termasuk data.

Tabel 2. Simbol-Simbol dan Keterangan DFD ${ }^{[5]}$

\begin{tabular}{|c|c|c|c|}
\hline No & Simbol & Arti & Keterangan \\
\hline 1. & & Entitas & $\begin{array}{l}\text { Digunakan untuk memberikan input atau } \\
\text { menerima output dari system }\end{array}$ \\
\hline 2. & & Aliran data & $\begin{array}{l}\text { Aliran data ini menunjukan arus data yang } \\
\text { berupa masukan untuk sistem berupa hasil dari } \\
\text { proses }\end{array}$ \\
\hline 3. & & Proses & $\begin{array}{l}\text { Suatu arus data yang masuk kedalam proses } \\
\text { untuk di olah sesuai proses yang dilakukanya. }\end{array}$ \\
\hline 4. & & Penyimpanan data & $\begin{array}{l}\text { Merupakan penyimpanan dari data yang berupa } \\
\text { file/database yang tersimpan di sistem komputer. }\end{array}$ \\
\hline
\end{tabular}

3. Entity-Relationship Diagram (ERD) adalah abstrak dan konseptual presentasi data yang termasuk salah satu rancangan atau metode basis data yang menhasilkan selema terkonsep untuk model data sistematik. 
Tabel 3. Notasi ERD ${ }^{[5]}$

\begin{tabular}{|c|c|c|c|}
\hline No & Simbol & Nama Simbol & Keterangan \\
\hline 1. & & Entitas & $\begin{array}{l}\text { Orang, tempat, atau benda memiliki nama } \\
\text { tunggal }\end{array}$ \\
\hline 2. & & Atribut & $\begin{array}{l}\text { Pendeskripsian karakteristik dari entitas. } \\
\text { digambarkan berbentuk lingkaran atau elips. } \\
\text { Atribut yang diberigaris bawah sebagai kunci } \\
\text { entitas/key. }\end{array}$ \\
\hline 3. & & Relasi & $\begin{array}{l}\text { Hubungan antara sejumlah entitas yang berasal } \\
\text { dari himpunan entitas yang berbeda-beda. }\end{array}$ \\
\hline 4. & & Penghubung & $\begin{array}{l}\text { Penghubung antara himpunan relasi dengan } \\
\text { himpunan entitas, himpunan entitas dengan } \\
\text { himpunan entity, atribut dinyatakan dalam } \\
\text { bentuk garis. }\end{array}$ \\
\hline
\end{tabular}

\section{METODE}

Penelitian ini dilakukan di kantor PT. Berkatmas Mulia Guna yang beralamat di Ruko Perum Pesona Permata Gading 1 block L no 23 Bluru, Lingkar Timur Kecamatan Candi Kabupaten Sidoarjo dan di Laboratorium Informatika Universitas Muhammadiyah Sidoarjo pada tanggal 1 Maret sampai 1 juni 2020. Dalam penelitin ini, proses pengumpulan data dilakukan sesuai dengan kejadian yang dibutuhkan di lapangan, dengan cara sebagai berikut :

1. Observasi yaitu pengamatan dalam pengumpulan data dengan melakukannya secara langsung di tempat perusahaan dan mencari apa saja yang dibutuhkan untuk bisa di jadikan sebagai bahan penunjang dalam aplikasi.

2. Wawancara atau interview bertanya secara langsung kepada Kepala atau Pegawai PT. Berkatmas Mulia Guna pada saat berlangsungnya Proses keluar masuk barang, untuk memperoleh keterangan yang lebih jalas.

Perancangan dan pembuatan sistem ini menggunakan perangkat lunak Website dan Database MySQL Yang berjalan Pada Sistem Operasi Windows, perancangan sistem terdiri sebagai berikut :

\section{A. Flowchart sistem}

a. Admin Kantor

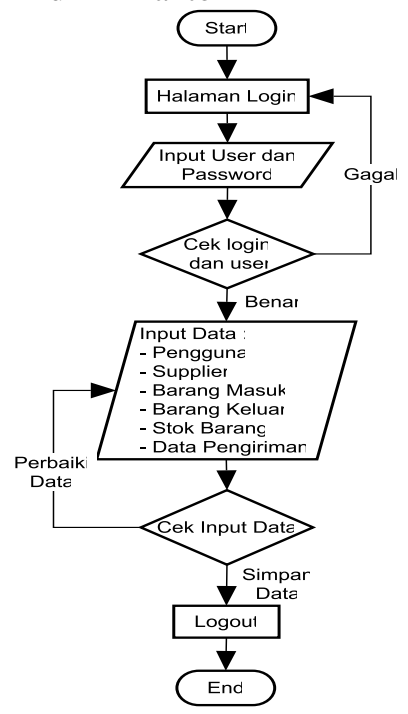

Gambar 1. Flowchart Admin Kantor Sistem Informasi Inventory Stok Barang c. Admin Gudang

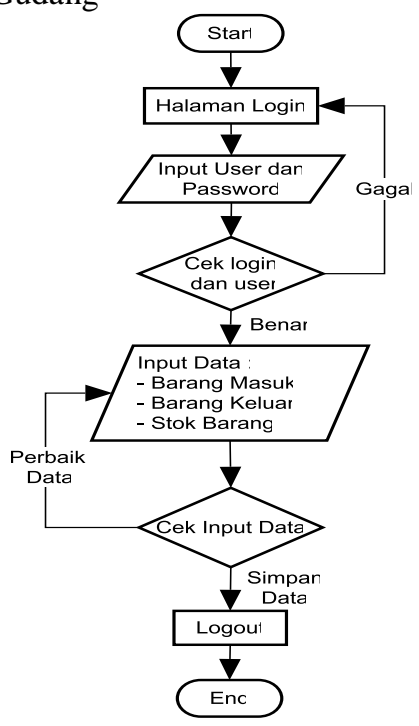

Gambar 2. Flowchart Admin Gudang Sistem Informasi Inventory Stok Barang 


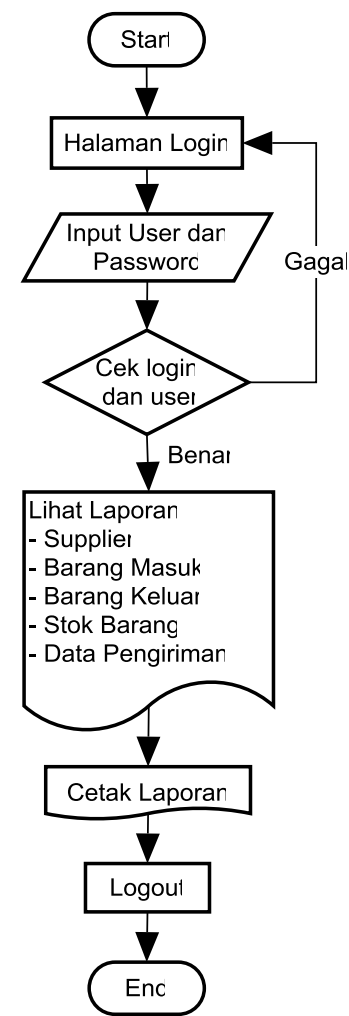

Gambar 3. Flowchat Pimpinan Sistem Informasi Inventory Stok Barang

\section{B. Data flow diagram (DFD)}

DFD sistem informasi inventory stok barang level 1

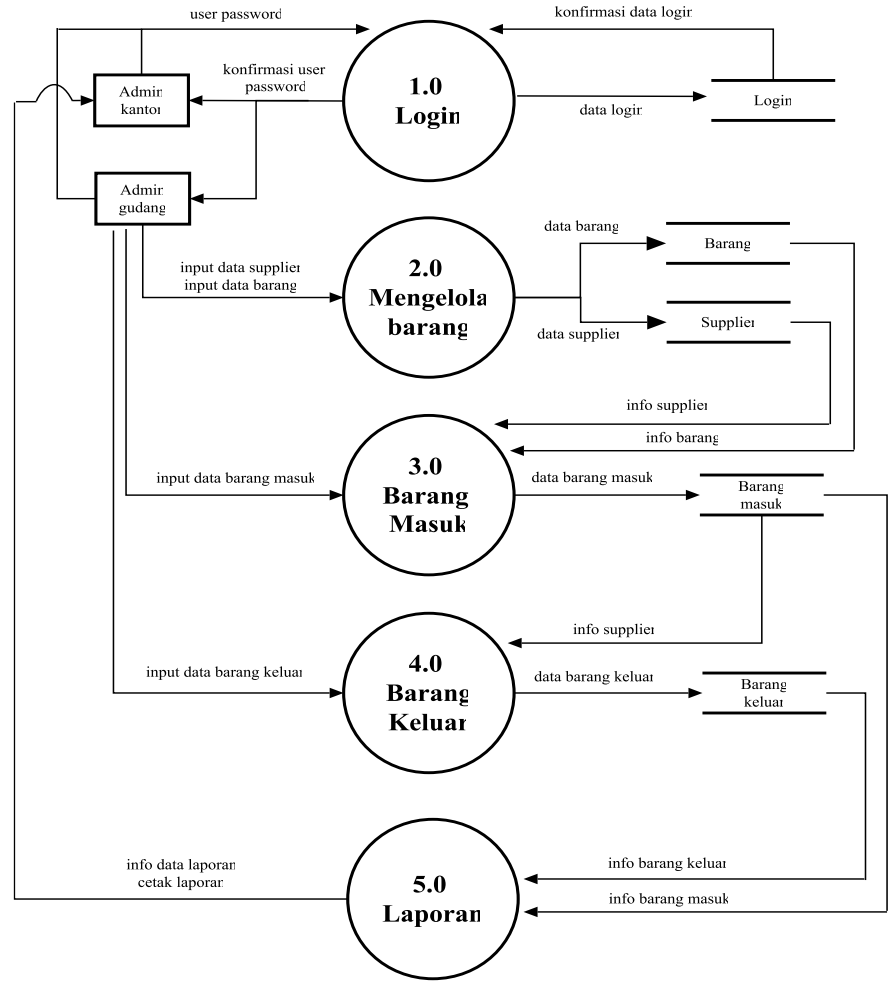

Gambar 4. DFD Level 1 Sistem Informasi Inventory Stok Barang 


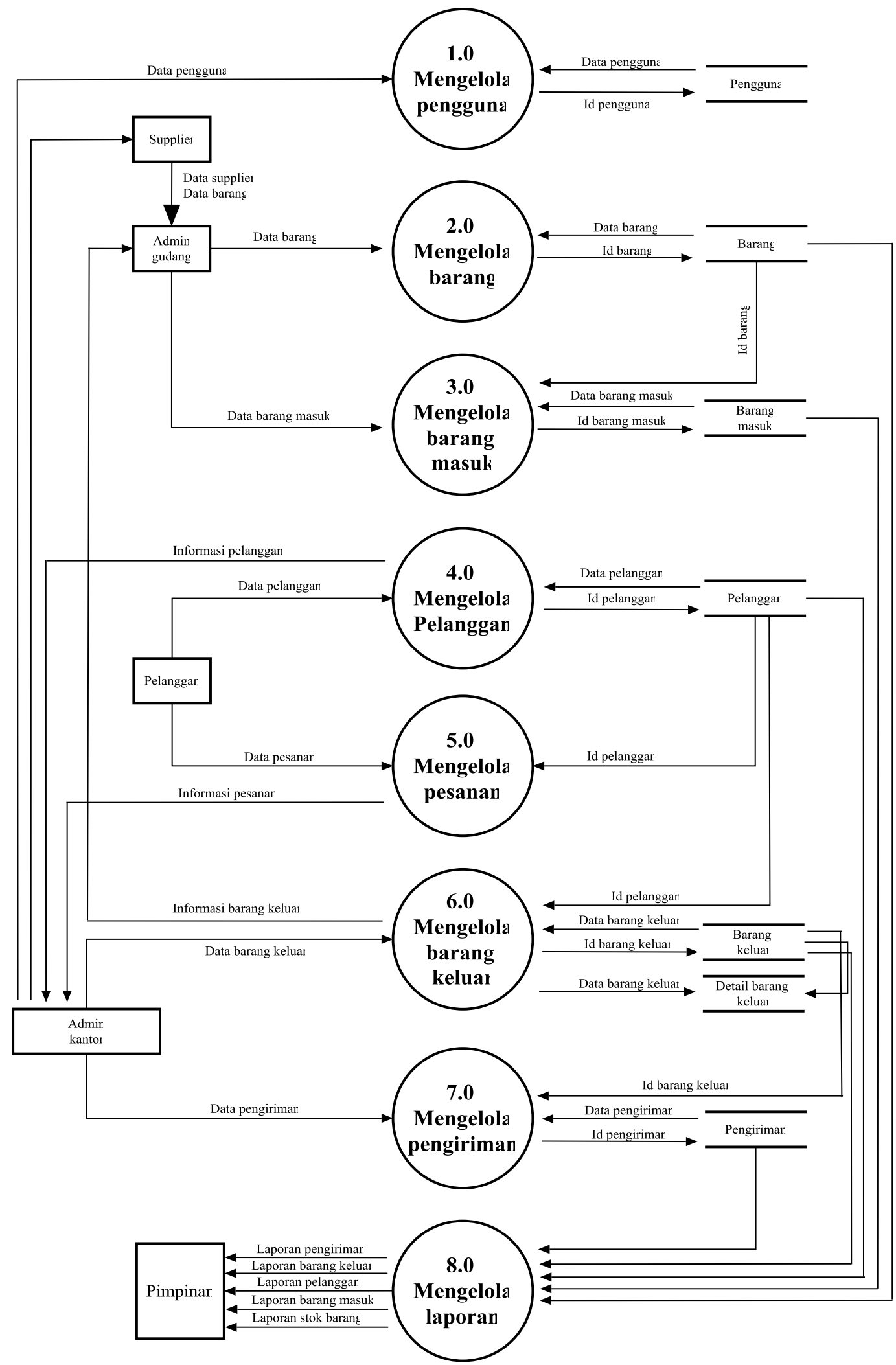

Gambar 5. DFD Level 2 Sistem Informasi Inventory Stok Barang

\section{Hasil dan Pembahasan}

A. Sistem informasi inventory stok barang diakses admin kantor 


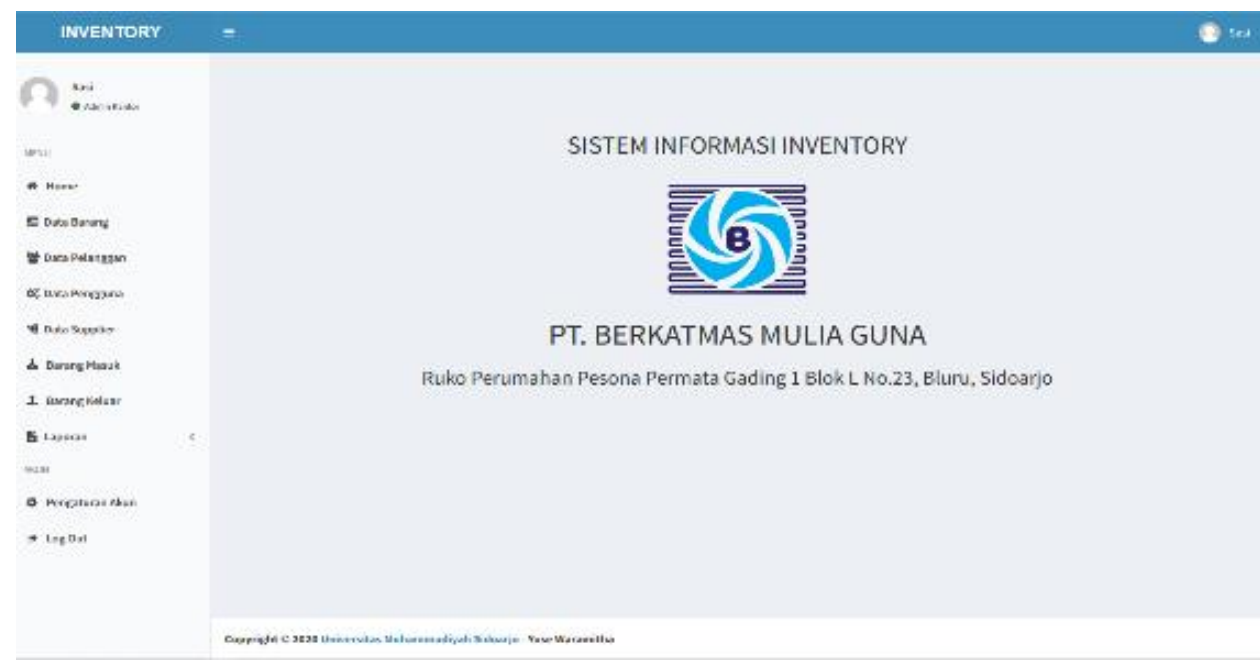

Gambar 6. Home Admin Kantor

Tabel 4. Uji Coba Sistem Pada Admin Kantor

\begin{tabular}{|c|c|c|c|c|}
\hline No & Penguji & Cara Pengujian & Hasil Pengamatan & Ket \\
\hline 1. & Login & $\begin{array}{l}\text { memasukkan } \\
\text { username dan } \\
\text { password }\end{array}$ & $\begin{array}{l}\text { Bisa masuk ke interface sesuai hak } \\
\text { akses login }\end{array}$ & ok \\
\hline 2. & Data pelanggan & $\begin{array}{l}\text { Pilih menu data } \\
\text { pelanggan }\end{array}$ & Bisa menampilkan data pelanggan & ok \\
\hline 3. & $\begin{array}{l}\text { Tambah } \\
\text { pelanggan }\end{array}$ & $\begin{array}{l}\text { Pilih icon tambah } \\
\text { pelanggan }\end{array}$ & $\begin{array}{l}\text { Bisa menambahkan data pelanggan } \\
\text { baru }\end{array}$ & ok \\
\hline 4. & Edit pelanggan & $\begin{array}{l}\text { Pilih icon edit } \\
\text { pelanggan }\end{array}$ & $\begin{array}{l}\text { Bisa merubah data pelanggan yang } \\
\text { telah tersimpan }\end{array}$ & ok \\
\hline 5. & $\begin{array}{l}\text { Hapus } \\
\text { pelanggan }\end{array}$ & $\begin{array}{l}\text { Pilih icon hapus } \\
\text { pelanggan }\end{array}$ & $\begin{array}{l}\text { Admin dapat menghapus data } \\
\text { pelanggan yang telah tersimpan }\end{array}$ & ok \\
\hline 6. & Data pengguna & $\begin{array}{l}\text { Pilih menu data } \\
\text { pengguna }\end{array}$ & Bisa menampilkan data pengguna & ok \\
\hline 7. & $\begin{array}{l}\text { Tambah } \\
\text { pengguna }\end{array}$ & $\begin{array}{l}\text { Pilih icon tambah } \\
\text { pengguna }\end{array}$ & $\begin{array}{l}\text { Bisa menambahkan data pengguna } \\
\text { baru }\end{array}$ & ok \\
\hline 8. & Edit pengguna & $\begin{array}{l}\text { Pilih icon edit } \\
\text { pengguna }\end{array}$ & $\begin{array}{l}\text { Bisa merubah data pengguna yang } \\
\text { telah tersimpan }\end{array}$ & ok \\
\hline 9. & Hapus pengguna & $\begin{array}{l}\text { Pilih icon hapus } \\
\text { pengguna }\end{array}$ & $\begin{array}{l}\text { Bisa menghapus data pengguna } \\
\text { yang telah tersimpan }\end{array}$ & ok \\
\hline 10. & Data supplier & $\begin{array}{l}\text { Pilih menu data } \\
\text { supplier }\end{array}$ & Bisa menampilkan data supplier & ok \\
\hline 11. & Tambah supplier & $\begin{array}{l}\text { Pilih icon tambah } \\
\text { supplier }\end{array}$ & $\begin{array}{l}\text { Bisa menambahkan data supplier } \\
\text { baru }\end{array}$ & ok \\
\hline 12. & Edit supplier & $\begin{array}{l}\text { Pilih icon edit } \\
\text { supplier }\end{array}$ & $\begin{array}{l}\text { Bisa merubah data supplier yang } \\
\text { telah tersimpan }\end{array}$ & ok \\
\hline 13. & Hapus supplier & $\begin{array}{l}\text { Pilih icon hapus } \\
\text { supplier }\end{array}$ & $\begin{array}{l}\text { Admin dapat menghapus data } \\
\text { supplier yang telah tersimpan }\end{array}$ & ok \\
\hline 14. & Data barang & Pilih menu barang & Bisa menampilkan data barang & ok \\
\hline 15. & $\begin{array}{l}\text { Tambah barang } \\
\text { baru }\end{array}$ & $\begin{array}{l}\text { Pilih icon tambah } \\
\text { barang }\end{array}$ & Bisa menambahkan barang baru & ok \\
\hline 16. & Edit data barang & $\begin{array}{l}\text { Pilih icon edit } \\
\text { barang }\end{array}$ & $\begin{array}{l}\text { Bisa merubah data barang yang } \\
\text { telah tersimpan }\end{array}$ & ok \\
\hline 17. & $\begin{array}{l}\text { Hapus data } \\
\text { barang }\end{array}$ & $\begin{array}{l}\text { Pilih icon hapus } \\
\text { barang }\end{array}$ & $\begin{array}{l}\text { Bisa menghapus data barang yang } \\
\text { telah tersimpan }\end{array}$ & ok \\
\hline
\end{tabular}


Procedia of Engineering and Life Science Vol.1 No. 1 March 2021

Seminar Nasional \& Call for Paper Fakultas Sains dan Teknologi (SENASAINS $1^{\text {st }}$ )

Universitas Muhammadiyah Sidoarjo

\begin{tabular}{lllll}
\hline 18. & Barang masuk & $\begin{array}{l}\text { Pilih menu barang } \\
\text { masuk }\end{array}$ & $\begin{array}{l}\text { Bisa menampilkan data barang } \\
\text { masuk }\end{array}$ & ok \\
\hline 19. & $\begin{array}{l}\text { Tambah barang } \\
\text { masuk }\end{array}$ & $\begin{array}{l}\text { Pilih icon tambah } \\
\text { barang masuk }\end{array}$ & $\begin{array}{l}\text { Bisa menambah data barang masuk } \\
\text { baru }\end{array}$ & ok \\
\hline 20. & $\begin{array}{l}\text { Edit barang } \\
\text { masuk }\end{array}$ & $\begin{array}{l}\text { Pilih icon edit } \\
\text { barang masuk }\end{array}$ & $\begin{array}{l}\text { Bisa merubah data barang masuk } \\
\text { yang telah tersimpan }\end{array}$ & ok \\
\hline 21. & $\begin{array}{l}\text { Hapus barang } \\
\text { masuk }\end{array}$ & $\begin{array}{l}\text { Pilih icon hapus } \\
\text { barang masuk }\end{array}$ & $\begin{array}{l}\text { Bisa menghapus data barang masuk } \\
\text { yang telah tersimpan }\end{array}$ & ok \\
\hline 22. & Barang keluar & $\begin{array}{l}\text { Pilih menu } \\
\text { barang keluar }\end{array}$ & $\begin{array}{l}\text { Bisa menampilkan data barang } \\
\text { keluar }\end{array}$ & ok \\
\hline 23. & $\begin{array}{l}\text { Tambah barang } \\
\text { keluar }\end{array}$ & $\begin{array}{l}\text { Pilih icon tambah } \\
\text { barang keluar }\end{array}$ & Bisa menambah barang keluar & ok \\
\hline 24. & $\begin{array}{l}\text { Tambah } \\
\text { pengiriman }\end{array}$ & $\begin{array}{l}\text { Pilih icon tambah } \\
\text { pengiriman }\end{array}$ & Bisa menambah data pengiriman & ok \\
\hline 25. & $\begin{array}{l}\text { Simpan dan } \\
\text { cetak }\end{array}$ & $\begin{array}{l}\text { Pilih icon } \\
\text { simpan dan cetak }\end{array}$ & $\begin{array}{l}\text { Bisa menyimpan dan mencetak } \\
\text { surat jalan }\end{array}$ & ok \\
\hline 26. & Log Out & Pilih menu logout & Keluar interface admin kantor & ok \\
\hline
\end{tabular}

\section{B. Sistem informasi inventory stok barang diakses admin gudang}

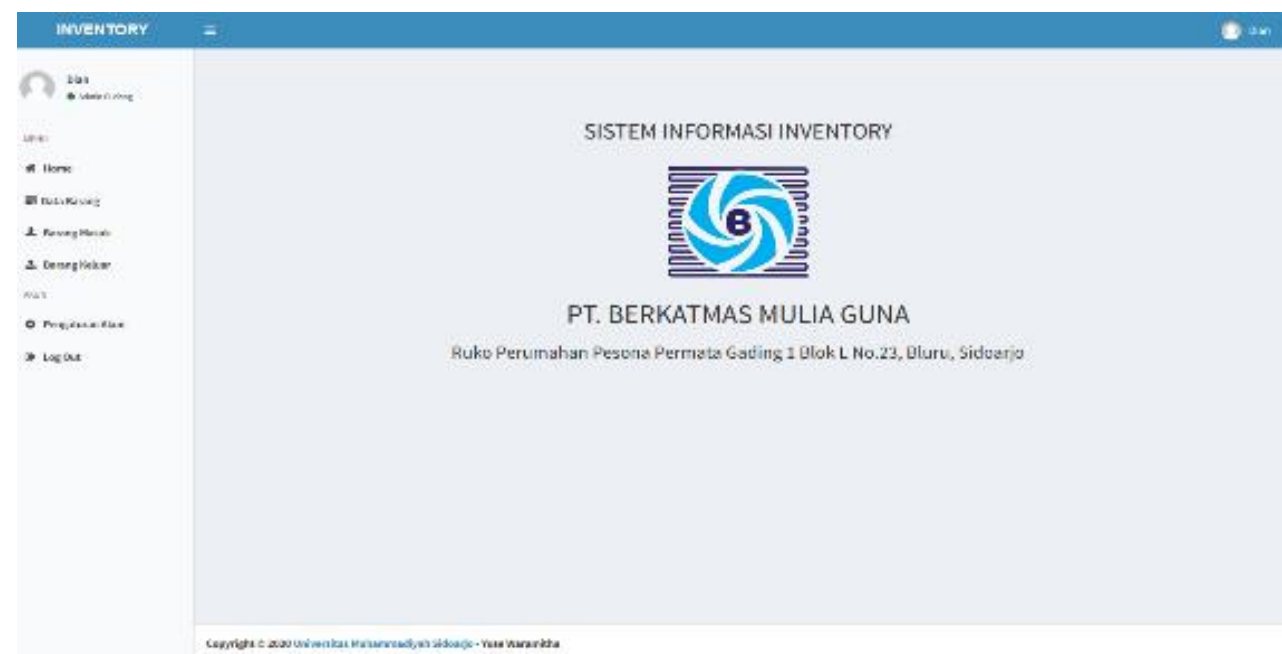

Gamber 7. Home Admin Gudang

Tabel 5. Uji Coba Sistem Pada Admin Gudang

\begin{tabular}{cllll}
\hline No & \multicolumn{1}{c}{ Penguji } & Cara Pengujian & \multicolumn{1}{c}{ Hasil Pengamatan } & Ket \\
\hline 1. & Login & $\begin{array}{l}\text { memasukkan } \\
\text { username dan } \\
\text { password }\end{array}$ & $\begin{array}{l}\text { Bisa masuk ke interface sesuai hak } \\
\text { akses login }\end{array}$ & ok \\
\hline 2. & Data barang & $\begin{array}{l}\text { Pilih menu } \\
\text { barang }\end{array}$ & Bisa menampilkan data barang & ok \\
\hline 3. & $\begin{array}{l}\text { Tambah } \\
\text { barang baru }\end{array}$ & $\begin{array}{l}\text { Pilih icon tambah } \\
\text { barang }\end{array}$ & Bisa menambahkan barang baru & ok \\
\hline 4. & $\begin{array}{l}\text { Edit data } \\
\text { barang }\end{array}$ & $\begin{array}{l}\text { Pilih icon edit } \\
\text { barang }\end{array}$ & $\begin{array}{l}\text { Bisa merubah data barang yang telah } \\
\text { tersimpan }\end{array}$ & ok \\
\hline 5. & $\begin{array}{l}\text { Hapus data } \\
\text { barang }\end{array}$ & $\begin{array}{l}\text { Pilih icon hapus } \\
\text { barang }\end{array}$ & $\begin{array}{l}\text { Bisa menghapus data barang yang } \\
\text { telah tersimpan }\end{array}$ & ok \\
\hline 6. & Barang masuk & $\begin{array}{l}\text { Pilih menu } \\
\text { barang masuk }\end{array}$ & $\begin{array}{l}\text { Bisa menampilkan data barang } \\
\text { masuk }\end{array}$ & ok \\
\hline 7. & $\begin{array}{l}\text { Tambah } \\
\text { barang masuk }\end{array}$ & $\begin{array}{l}\text { Pilih icon tambah } \\
\text { barang masuk }\end{array}$ & $\begin{array}{l}\text { Bisa menambah data barang masuk } \\
\text { baru }\end{array}$ & ok \\
\hline
\end{tabular}


Procedia of Engineering and Life Science Vol.1 No. 1 March 2021

Seminar Nasional \& Call for Paper Fakultas Sains dan Teknologi (SENASAINS 1st)

Universitas Muhammadiyah Sidoarjo

\begin{tabular}{cllll}
\hline 8. & $\begin{array}{l}\text { Edit barang } \\
\text { masuk }\end{array}$ & $\begin{array}{l}\text { Pilih icon edit } \\
\text { barang masuk }\end{array}$ & $\begin{array}{l}\text { Bisa merubah data barang masuk } \\
\text { yang telah tersimpan }\end{array}$ & ok \\
\hline 9. & $\begin{array}{l}\text { Hapus barang } \\
\text { masuk }\end{array}$ & $\begin{array}{l}\text { Pilih icon hapus } \\
\text { barang masuk }\end{array}$ & $\begin{array}{l}\text { Bisa menghapus data barang masuk } \\
\text { yang telah tersimpan }\end{array}$ & ok \\
\hline 10. & Barang keluar & $\begin{array}{l}\text { Pilih menu barang } \\
\text { keluar }\end{array}$ & $\begin{array}{l}\text { Bisa menampilkan data barang } \\
\text { keluar }\end{array}$ & ok \\
\hline 11 & $\begin{array}{l}\text { Tambah } \\
\text { barang keluar }\end{array}$ & $\begin{array}{l}\text { Pilih icon tambah } \\
\text { barang keluar }\end{array}$ & Bisa menambah barang keluar & ok \\
\hline 12. & Log Out & Pilih menu logout & Keluar interface admin gudang & ok \\
\hline
\end{tabular}

\section{Sistem informasi inventory stok barang diakses pimpinan}

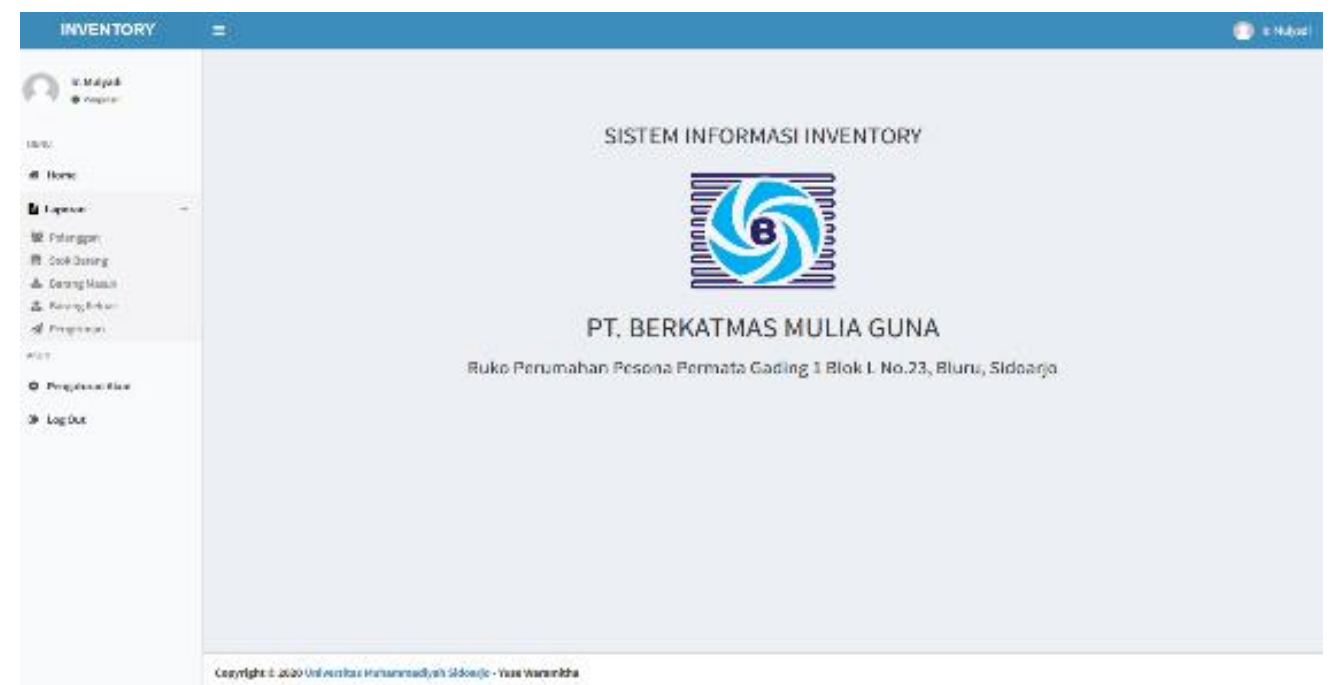

Gamber 8. Home Pimpinan

Tabel 6. Uji Coba Sistem Pada Admin Gudang

\begin{tabular}{lllll}
\hline No & \multicolumn{1}{c}{ Penguji } & Cara Pengujian & \multicolumn{1}{c}{ Hasil Pengamatan } & Ket \\
\hline 1. & Login & $\begin{array}{l}\text { Pimpinan } \\
\text { memasukkan } \\
\text { username dan } \\
\text { password }\end{array}$ & $\begin{array}{l}\text { Bisa masuk ke interface sesuai hak } \\
\text { akses login }\end{array}$ & ok \\
\hline 2. & $\begin{array}{l}\text { Laporan data } \\
\text { pelanggan }\end{array}$ & $\begin{array}{l}\text { Pilih menu } \\
\text { laporan pelanggan }\end{array}$ & $\begin{array}{l}\text { Bisa menampilkan dan mencetak } \\
\text { laporan pelanggan }\end{array}$ & ok \\
\hline 3. & $\begin{array}{l}\text { Laporan stok } \\
\text { barang }\end{array}$ & $\begin{array}{l}\text { Pilih menu } \\
\text { laporan stok }\end{array}$ & $\begin{array}{l}\text { Bisa menampilkan dan mencetak } \\
\text { laporan stok barang }\end{array}$ & ok \\
\hline 4. & $\begin{array}{l}\text { Laporan } \\
\text { barang masuk }\end{array}$ & $\begin{array}{l}\text { Pilih menu } \\
\text { laporan } \\
\text { barang masuk }\end{array}$ & $\begin{array}{l}\text { Bisa menampilkan dan mencetak } \\
\text { data laporan barang masuk }\end{array}$ & ok \\
\hline 5. & $\begin{array}{l}\text { Laporan } \\
\text { barang keluar }\end{array}$ & $\begin{array}{l}\text { Pilih menu } \\
\text { laporan } \\
\text { barang keluar }\end{array}$ & $\begin{array}{l}\text { Bisa menampilkan dan mencetak } \\
\text { laporan barang keluar }\end{array}$ & ok \\
\hline 6. & $\begin{array}{l}\text { Laporan } \\
\text { pengiriman }\end{array}$ & $\begin{array}{l}\text { Pilih menu } \\
\text { laporan } \\
\text { pengiriman }\end{array}$ & $\begin{array}{l}\text { Bisa menampilkan dan mencetak } \\
\text { laporan pengiriman }\end{array}$ & ok \\
\hline 7. & Log Out & Pilih menu logout & Keluar interface pimpinan & ok \\
\hline
\end{tabular}

\section{KESIMPULAN}

Setelah melalui beberapa tahapan dalam menyelesaikan Aplikasi Sistem Informasi Inventory Stok Barang Pada PT Berkatmas Mulia Guna, terdapat kesimpulan diantaranya adalah mempermudah proses pendataan barang masuk 
dan barang keluar, lebih mudah mencari data yang diperlukan dan dapat mempermudah dalam memberikan informasi. Sistem informasi inventory yang dibangun ini dapat mendata pengiriman, barang masuk dan barang keluar yang sudah otomatis tersimpan, dan dengan adanya laporan dapat menampilkan hasil yang akurat. Aplikasi inventory ini dapat mempermudah dalam pencarian stok barang yang telah disimpan dan dapat menghemat waktu serta menampilkan hasil yang akurat.

\section{UCAPAN TERIMA KASIH}

Peneliti mengucapkan terima kasih banyak kepada pihak Kantor PT. Berkatmas Mulia Guna yang telah memperbolehkan menggunakan data barang masuk dan barang keluar yang ada di perusahaan untuk di jadikan bahan dalam pembuatan aplikasi dan laboratoruin Universitas Muhammadiyah sebagai tempat untuk proses perancangan dan pembuatan aplikasi, serta tidak lupa pula saya ucapkan terima kasih kepada Ir. Sumarno, MM. selaku validator dan semua pihak yang membantu dalam penelitian ini.

\section{REFERENSI}

[1] Edwards, Chris, 2001, Sistem Informasi Edisi 2, Andi, Yogyakarta.

[2] Hartono, Jogianto, 1990, Analisis dan Desain Sistem Informasi Pendekatan terstruktur teori dan praktek aplikasi bisnis.Andi, Yogyakarta.

[3] Jogiyanto, HM. 2005. Analisis dan Desain, Sistem Informasi Pendekatan Terstruktur teori \& Praktek Aplikasi Bisnis. Penerbit Andi, Yogyakarta.

[4] Hariyanto, Bambang. 2004. Sistem Manajemen BasisData: Pemodelan, Perancangan, dan Terapannya. Informatika, Bandung.

[5] Waljiyanto, (2003), Sistem Basis Data : Analisis dan Pemodelan Data. Graha Ilmu, Yogyakarta.

[6] Wicaksono, Titis., Fauzi, Moch, 2015, Sistem Inventory Control pada Laboratorium Komputer SMK Muhammadiyah Kajen Berbasis Web Dengan Framework Codeigniter, Jurnal Surya Informatika Vol 1 No 1November 2015.

[7] Sari, Wellia., Novitasari, Petra, 2015, Sistem Informasi Persediaan Barang Berbasis Web Pada Raja Bares Semarang, Jurnal Skripsi Universitas Dian Nuswantoro Semarang.

[8] Munthe, Ibnu, 2015, Sistem Inventaris Berbasis Web Pada Gudang Perusahaan, Jurnal Informatika AMIK-LB Vol 3 No 1-Januari 2015.

[9] Sukarno, Mohamad. 2006. Membangun Website Dinamis Interaktif dengan PHP- MySQL, Cetakan ke-1, Penerbit Eska Media Press, Jakarta.

[10] Sutabri, Tata. 2004. Analisa Sistem Informasi, Edisi 1. Penerbit Andi, Yogyakarta. 